\title{
Analysis of Traffic Accident Characteristics Using The EAN (Accident Equivalent Number) Method of The Case Study Narogong Road in Bekasi
}

\author{
Andri Irfan Rifai and Yopi Sopiya \\ Faculty of Engineering, University MercuBuana Jakarta, Indonesia \\ andrirfan@yahoo.com,yopiii80@gmail.com
}

\begin{abstract}
This study uses the Accident Equivalent Number (EAN) method based on the weighted value of accident victims with the accident fatality rate and the number of victims. The weighting of the accident rate is then determined by the EAN formula: $12 \mathrm{MD}+3 \mathrm{LB}+3 \mathrm{LR}+1 \mathrm{~K}$, then using the Upper Control Limit (BKA) formula to determine the ranking of accident-prone points with the formula $\mathrm{BKA}=\mathrm{C}+3 \sqrt{\mathrm{C}}$ to determine priority handling of accident-prone points. And using the road inventory survey method to find out the factors that cause accidents and efforts to handle accident-prone points appropriately Based on the results of the analysis it can be concluded that the Narogong road in the city of Bekasi is classified as an accident-prone area because it has an EAN value that exceeds the Upper Control Limit (BKA) value. The coordinate point of the location with the highest EAN value is segment three at the point -6.3145869 s.d '-6.3230043. (residential area of Vida Bekasi to Bantar Gebang market area) with an EAN value of 126 and a BKA value of 48.3. In this segment there have been 12 accidents with 7 fatalities, 2 seriously injured, 8 slightly injured with a material loss of Rp. 11,200,000. And the dominant type of accident is the front-rear hit-and-hit accident by $39 \%$ with the cause of the traffic accident being the driver factor by $76 \%$. Efforts to handle accident-prone points by holding counseling about safety riding, painting road markings, installing road signs as needed, and conducting routine checks of street lighting that is not functioning.
\end{abstract}

Keywords: Characteristics, Traffic Accidents, Accident Equivalent Number

\section{Introduction}

Land transportation, a part of transportation, also contributes to improving the economy in an area this can be seen that in regions that have a land transport network, as a means that can connect these areas with other regions, will have faster economic growth compared to isolated areas The movement of goods and people becomes faster and easier, and comfort for road users is the main goal. But on the other hand it creates problems that hinder the achievement of these goals. Increased traffic flow that causes congestion, delays, accidents and various other environmental problems that must be resolved. [1]

Based on the 2011 National Road Safety General Plan up to 2035, safety is one of the basic principles of transport organizers. In Indonesia this principle is often not in line with what is happening on the ground. This is indicated by the increasing number of fatalities of accident victims. [2]

An accident is defined as an unexpected and unintentional road event involving a vehicle with or without other road users, resulting in human casualties or property loss. Victims of traffic accidents can be in the form of death victims, serious injuries and minor injuries and are calculated no later than (30) days after the accident occurred.[3]

Narogong highway is a line that connects the city of Bekasi with Bogor regency, besides that there are several industries along the Narogong highway. And as the main access road to Bantar Gebang Final Disposal Site (TPA). With the type of vehicle with the heaviest load axis of more than 8 tons. Narogong highway is included in the classification of collector road with one-way lane and becomes one of the lanes with heavy traffic flow and is considered to have a high level of accident risk. 


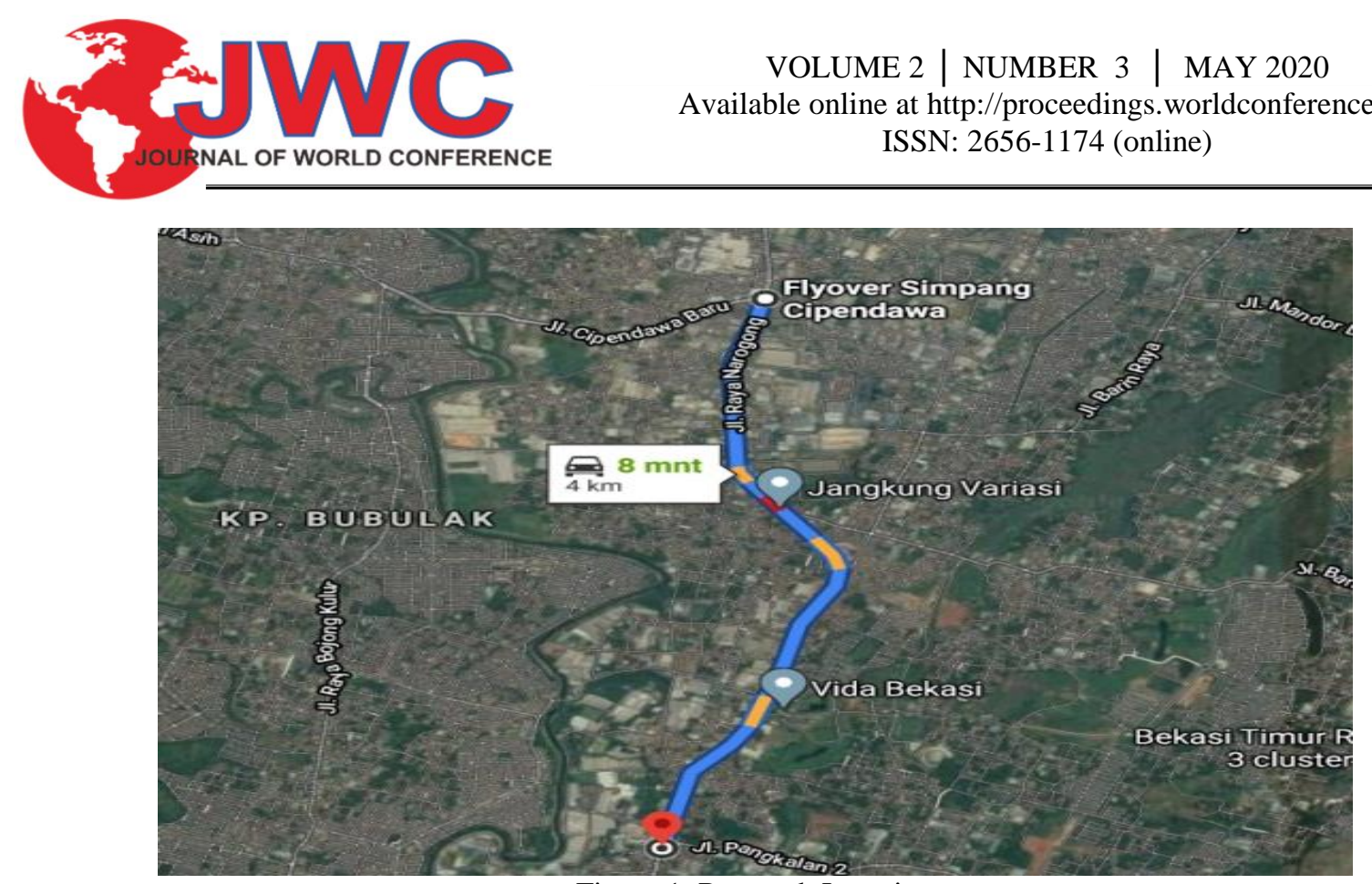

Figure 1. Research Location

Source: Data in Research,2020

\section{Methodology}

\subsection{Accident Equivalent Number}

Stages of analysis of the Accident Equivalent Number method with the Upper Control Limit, namely:

1 Location of the Bekasi city Narogong highway research with the number of traffic accident incidents originating from Bekasi City Police..

2 Determine the weight of the accident number on every Narogong highway in the city of Bekasi with a standard weighting table.

3 Calculate with the Accident Equivalent Numbers formula EAN $=12 M D+3 L B+3 L R+1 K$

4 Calculate the Upper Control Limit BKA $=\mathrm{C}+3 \sqrt{ } \mathrm{C}$

5 If the weight of the accident equivalent number exceeds the Upper Control Limit then the point is an accidentprone location.

The results of this analysis continue to look at the extent to which a type of accident that is considered dominant in an accident-prone location will be significantly different from the accident conditions on the Narogong highway in the city of Bekasi. After knowing the type of accident, it can provide suggestions for handling the dominant aspects on accident-prone roads.

The next step is to know the characteristics of the accident. The characteristics of the accident will illustrate the accident conditions on the Narogong highway in the city of Bekasi. Therefore, knowing the characteristics of the accident can determine the type of accident that affects traffic accidents.

The classification of accidents that will be used in this study are:

Factors that cause accidents, to find the dominant factors causing an accident.

1 Collision type, to find the dominant collision type at an accident site.

2 Road user involvement, grouped according to the type of vehicle.

3 Location of the incident, referring to the accident location environment.

4 The time of the incident, in terms of the weather conditions at the scene or the hour of the accident. 


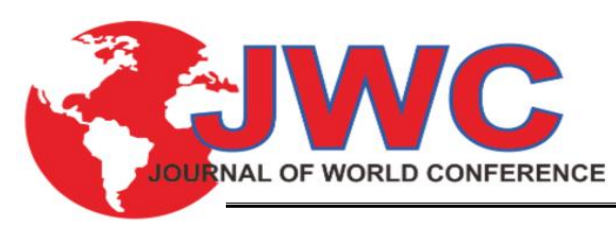

VOLUME 2 | NUMBER 3 | MAY 2020

Available online at http://proceedings.worldconference.id.

ISSN: 2656-1174 (online)
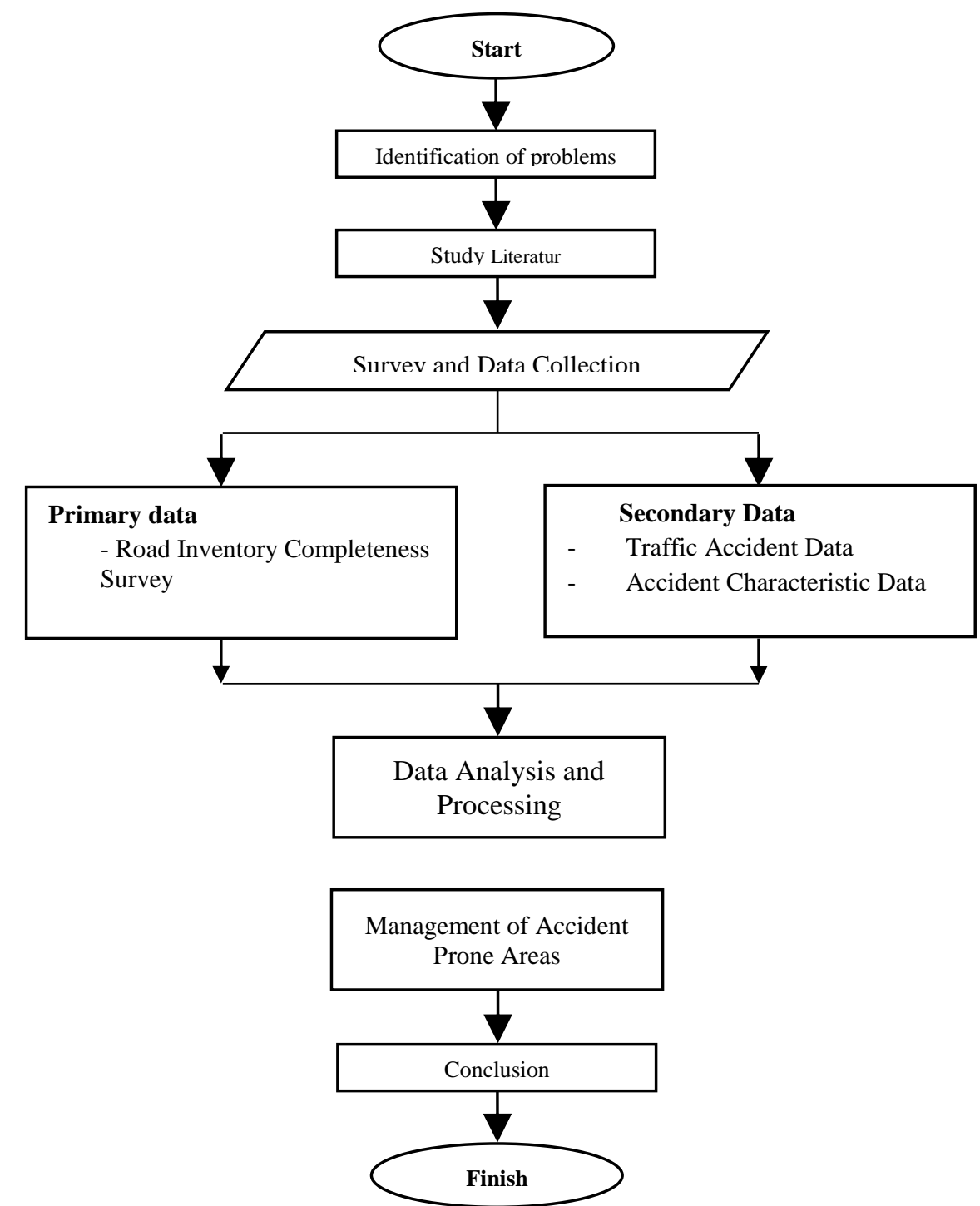

Figure 2 Research flow chart

Source: Data in Research,2020

The research data used in this study are secondary data that is accident data from the Bekasi City Police from 2015 to 2018 to find out the number of accidents, the type of accident and the time of the accident. Then the Primary data that is conducting a survey of road inventory such as road medians, road markings, traffic signs, road safety and road lighting conditions. And surveying the speed of vehicles on the narogong highway in the city of Bekasi. The data that has been collected is then processed using the following method.

\subsection{Survey of accident-prone locations}

Primary data were obtained from the results of field surveys on the Narogong highway in the city of Bekasi by using a checklist form comparing the actual conditions on the ground with the minimum standard of road service at the accident-prone locations in the third segment at the coordinates of -6.3145869 to 3.3230043. (residential area Vida Bekasi s.d Bantar Gebang market area). with the vehicle's actual average speed of $45.44 \mathrm{~km} / \mathrm{h}$ measured using a speed gun. 
Table 1 Road inventory surveys

\begin{tabular}{|c|c|c|c|c|}
\hline \multirow{2}{*}{ No } & \multirow{2}{*}{$\begin{array}{c}\text { Road safety and inventory } \\
\text { indicators }\end{array}$} & \multicolumn{2}{|c|}{ Completeness } & \multirow{2}{*}{ Information } \\
\hline & & Yes & No & \\
\hline 1 & Road Median & & $\sqrt{ }$ & \\
\hline 2 & Road signs & $\sqrt{ }$ & & $\begin{array}{l}\text { There are several signs that are damaged and blocked by } \\
\text { trees }\end{array}$ \\
\hline 3 & Road markings & & $\sqrt{ }$ & $\begin{array}{l}\text { Color has faded and the lack of zebra crossing at the } \\
\text { crossing point of the road }\end{array}$ \\
\hline 4 & Safety Fence / Pavement & & $\sqrt{ }$ & \\
\hline 5 & Road damage & $\sqrt{ }$ & & There are several potholes and uneven roads \\
\hline 6 & Street Lighting & $\sqrt{ }$ & & $\begin{array}{l}\text { There are several road points that are not exposed to } \\
\text { lighting }\end{array}$ \\
\hline & Total & 3 & 2 & \\
\hline
\end{tabular}

Based on table 3 coordinates of segment 3 (residential area Vida Bekasi s.d Bantar Gebang market area). After conducting a direct review, there were a number of factors triggering accidents on the Bekasi city narogong highway:

1 The Bekasi city Narogong highway is a connecting city road between Bekasi city and Bogor district, causing a significant level of mobilization on the road because many residents reside in Bekasi and Bogor regency but work in areas along the Narogong highway. This condition is not balanced with adequate infrastructure and facilities of roads and public transportation. This can be seen from the lack of traffic signs, road markings that do not exist and some faded road markings, guard rails / sidewalks, road damage or inadequate street lighting that can trigger accidents.

2 The existence of Bantar Gebang waste landfills so that many garbage trucks have the risk of disposing of slippery water which makes the road slippery and increases the potential for accidents during the rainy season.

\section{Results And Analysis}

\subsection{Accident Prone Location Identification}

The accident table data is based on segment division and the number of accident victims in table 2 .

Table 2 Segmentation Traffic Accident Data and material loss

\begin{tabular}{ccccccc}
\hline \multirow{2}{*}{ No } & \multicolumn{2}{c}{ Segmen } & \multicolumn{3}{c}{ Victim } & Material loss \\
\cline { 2 - 7 } & Start & finish & MD & LB & LR & (Rp) \\
\hline $\mathbf{1}$ & '-6.2976651 & $'-6.3073491$ & 5 & 0 & 12 & $6,600,000$ \\
\hline 2 & $'-6.3073491$ & $'-6.3145869$ & 3 & 2 & 8 & $11,000,000$ \\
\hline $\mathbf{3}$ & '-6.3145869 & '-6.3230043 & 3 & 7 & 2 & $11,200,000$ \\
\hline 4 & '-6.3230043 & '-6.331145 & 1 & 2 & 0 & $3,700,000$ \\
\hline \multicolumn{5}{c}{ Source: Data in Research,2020 }
\end{tabular}

From the accident data on the Narogong highway in the city of Bekasi, accidents often occur in segment three with the number of fatalities 3 people, the number of seriously injured 7 people, the number of minor injuries 2 people with a total loss of Rp 11,200,000.

\subsection{Determination of Accident Prone Areas}

If the value of EAN > BKA, then the area is an accident-prone area. On the Narogong Highway Bekasi city coordinates -6.2976651 to -6.3073491 , EAN value $=108$ with $\mathrm{BKA}=42.6$ then the road has EAN value $>\mathrm{BKA}$ higher than EAN value > BKA. 
Table 3 Segmentation of EAN and BKA values

\begin{tabular}{ccccccc}
\hline \multirow{2}{*}{ No. } & \multirow{2}{*}{ Segmen } & \multicolumn{2}{c}{ koordinat } & \multicolumn{3}{c}{ value } \\
\cline { 2 - 6 } & $\mathbf{3}$ & Start & Finish & EAN & BKA & Deviasi \\
\hline 1 & 1 & $-\mathbf{6 . 3 1 4 5 8 6 9}$ & $-\mathbf{6 . 3 2 3 0 0 4 3}$ & $\mathbf{1 2 6}$ & $\mathbf{4 8 . 3}$ & $\mathbf{- 7 7 . 7}$ \\
\hline 2 & $2-6.2976651$ & -6.3073491 & 108 & 42.6 & -65.4 \\
\hline 3 & 2 & -6.3073491 & $'-6.3145869$ & 76 & 32.1 & -43.9 \\
\hline 4 & 4 & -6.3230043 & -6.331145 & 55 & 24.9 & -30.1 \\
\hline
\end{tabular}

Source: Data in Research,2020

Based on table 3 it can be concluded that the Narogong highway in the city of Bekasi is classified as an area prone to traffic accidents because of the four segments having EAN value > BKA Narogong highway. And in the third segment has the highest deviation value that is the coordinate point $-\mathbf{6 . 3 1 4 5 8 6 9}$ to -6.3230043 (Vida housing area to Bantar Gebang market area) with a deviation value of -77.7 so it needs to be given special treatment especially to suppress the level of traffic accident prone on the road. Then in second place in segment one, then segment two and finally the four segment.

Tabel 4 Causing of Accident

\begin{tabular}{|c|c|c|c|}
\hline No & Description & Total & Persentase \\
\hline \multicolumn{4}{|c|}{ Driver Factor } \\
\hline 1 & Fatigue & 1 & $2.40 \%$ \\
\hline 2 & Off guard & 6 & $14.60 \%$ \\
\hline 3 & Sleepy & 2 & $4.90 \%$ \\
\hline 4 & Drunk & 1 & $2.40 \%$ \\
\hline 5 & Not skilled & 2 & $4.90 \%$ \\
\hline 6 & Undisciplined & 14 & $34.10 \%$ \\
\hline 7 & Not focus & 5 & $12.20 \%$ \\
\hline & Sub Total & 31 & $75.60 \%$ \\
\hline \multicolumn{4}{|c|}{ Vehicle Factor } \\
\hline 1 & Brake & 2 & $4.90 \%$ \\
\hline 2 & Tire & 1 & $2.40 \%$ \\
\hline 3 & Steering wheel & 0 & $0.00 \%$ \\
\hline 4 & Lighting & 0 & $0.00 \%$ \\
\hline 5 & Rearview mirror & 0 & $0.00 \%$ \\
\hline 6 & Horn & 0 & $0.00 \%$ \\
\hline 7 & Ineligible & 0 & $0.00 \%$ \\
\hline 8 & Overload & 1 & $2.40 \%$ \\
\hline & Sub Total & 4 & $9.80 \%$ \\
\hline \multicolumn{4}{|c|}{ Road Factor } \\
\hline 1 & Perforated & 0 & $0.00 \%$ \\
\hline 2 & Wavy & 0 & $0.00 \%$ \\
\hline 3 & Slippery & 1 & $2.40 \%$ \\
\hline 4 & Road Slope & 0 & $0.00 \%$ \\
\hline 5 & Signs not suitable & 0 & $0.00 \%$ \\
\hline 6 & There are no signs & 2 & $4.90 \%$ \\
\hline 7 & Road markings & 2 & $4.90 \%$ \\
\hline 8 & Bend in the road & 0 & $0.00 \%$ \\
\hline 9 & Facilities and infrastructure & 0 & $0.00 \%$ \\
\hline & Sub Total & 5 & $12.20 \%$ \\
\hline \multicolumn{4}{|c|}{ Environmental factor } \\
\hline 1 & Rain & 1 & $2.40 \%$ \\
\hline 2 & Foggy & 0 & $0.00 \%$ \\
\hline 3 & Avalanche & 0 & $0.00 \%$ \\
\hline 4 & Flood & 0 & $0.00 \%$ \\
\hline & Sub Total & 1 & $2.40 \%$ \\
\hline & Total & 41 & $100 . \%$ \\
\hline
\end{tabular}

Source: Data in Research,2020 
From the data of the causes of accidents above the most dominant cause is the driver factor as much as 31 the number of accidents $75.6 \%$ then the road factor $12.2 \%$ and the vehicle factor $9.8 \%$.

Accident characteristics data contains the type of accident, time of incident, and the total number of accident victims that occurred on the Narogong highway in Bekasi City.

Table 5 Types of Accidents

\begin{tabular}{cccc}
\hline No & Types of Accidents & Total & Persentase \\
\hline 1 & Single & 1 & $2 \%$ \\
\hline 2 & Front-front & 13 & $32 \%$ \\
\hline 3 & Front back & 16 & $39 \%$ \\
\hline 4 & Front - Side & 4 & $10 \%$ \\
\hline 5 & Side-by-side & 1 & $2 \%$ \\
\hline 6 & Streak & 0 & $0 \%$ \\
\hline 7 & Pedestrian & 2 & $5 \%$ \\
\hline 8 & Silent object & 4 & $10 \%$ \\
\hline & Total & 41 & $100 \%$ \\
\hline
\end{tabular}

Source: Data in Research,2020

From table 5 above there are 8 types of accidents that occur on the Narogong Highway of Bekasi City, which often occur are 16 front-and-back crashes and 13 front-and-back crashes of $39 \%$.

Tabel 6 Time of the Accident

\begin{tabular}{cccc}
\hline No & Description & Total & Persentase \\
\hline 1 & Dark conditions $(18.00-06.00)$ & 19 & $46 \%$ \\
\hline 2 & Bright condition $(06.00-18.00)$ & 22 & $54 \%$ \\
\hline & Total & 41 & $100 \%$ \\
\hline
\end{tabular}

Source: Data in Research,2020

From the data in table 6, accidents that occur in bright conditions are $54 \%$ and accidents that occur during dark conditions are $46 \%$.

\section{Conclusion}

1 Based on the analysis of accident prone on the Bekasi city Narogong road in 2015 - 2018 by using the Accident Equivalent Number (EAN) method, it was concluded that the Bekasi city Narogong road is an accident-prone area because the road has an EAN value exceeding the Upper Control Limit (BKA) value. The coordinate point of the location with the highest EAN value is the third segment at the point -6.3145869 until -6.3230043 . (Vida Bekasi housing area to Bantar gebang market area) with EAN value of 126 and BKA value of 48.3. In this segment there have been 12 accidents with 7 fatalities, 2 seriously injured, 8 slightly injured with a material loss of Rp. $11,200,000$. While the type of accidents that occurred on the Narogong highway in 2015-2018 was the most dominant type of crash-hit front-back by $39 \%$.

2 While the factors that cause traffic accidents on the Narogong road Bekasi city in 2015 - 2018 include:

a. The dominant factor causing traffic accidents is the driver factor with a percentage of $75.6 \%$, this is because there are still many drivers or road users who are not disciplined about traffic safety rules and awareness for safety riding.

b. Lack of pedestrian facilities such as zebra crossing to cross the street. The condition of the road markings has faded and the road surface has holes and uneven surfaces and some points that are not exposed to street lighting are additional factors that can trigger accidents.

c. The existence of the Bantar Gebang rubbish landfill site is passed so that garbage trucks are at risk of removing slippery water which makes the road slippery and increases the potential for accidents during the rainy season.

\section{Suggestion}

1 Need to hold counseling about the importance of safety riding for motorists and carry out special operations from the police to minimize drivers who are disorderly or do not have a driving license. 
2 Install road signs that meet the road requirements. carry out repairs of road signs that have faded or damaged as well as maintenance of plants or trees that obstruct motorists' views of road signs or traffic lights. Carry out repairs to potholes and add street lighting and maintenance of street lights that are no longer functioning properly. And build special facilities for pedestrians.

\section{References:}

[1] BPS RI. (2017). Statistik Transportasi Darat. Indonesia: BPS RI

[2]Departemen Perhubungan. (2011). Rencana Umum Nasional Keselamatan (RUNK) Jalan 2011-2035. Departemen Perhubungan.

[2]Peraturan Pemerintah Tahun 1993 tentang Prasarana dan Lalu lintas Jalan.

\section{Biographies}

Andri Irfan Rifai is a lecturer at MercuBuana University and head of the bachelor program in civil engineering in BatamInternasional University. He earned Bachelor in civil engineering in Sebelas Maret University, Master in civil engineering from University of Indonesia and PhD in Transportation Engineering from University of Indonesia Universidade do Minho, Portugal. Dr. Andri Irfan is also works in Indonesia Ministry of Public Works and Housing as Project Manager at Rehabilitation and Reconstruction project in Palu Disaster Area.

Yopi Sopiyan is a student of the Faculty of Civil Engineering at Mercu Buana University in 2015 and successfully completed her undergraduate education in February 2020. Mr. Yopi Sopiyan also works in a private contracting company as a housing project admin, with a general high school education background with social graduates in 2012 . 